\title{
Planktic Cyanobacteria from São Paulo State, Brazil: Chroococcales
}

\author{
CÉLIA L. SANT’ANNA ${ }^{1,4}$, MARIA TERESA DE P. AZEVEDO ${ }^{1}$, PEDRO AMÉRICO C. SENNA ${ }^{\dagger}$, \\ JIRÍ KOMÁREK ${ }^{2}$ and JAROSLAVA KOMÁRKOVÁ ${ }^{3}$
}

(received: March 5, 2003; accepted: November 27, 2003)

\begin{abstract}
Planktic Cyanobacteria from São Paulo State, Brazil: Chroococcales). The biodiversity studies of planktic cyanobacteria started in 1997 with intensive collecting in different water bodies of São Paulo State. Due to the problems brougth by eutrophication and cyanobacterial blooms, the samplings were concentrated in reservoirs of Alto Tietê region that supply drinking water to millions of people. The samples were collected with $20 \mu \mathrm{m}$ plankton net or Van Dorn's bottle. Part of each one was preserved in formaldehyde or lugol solution and part was isolated. The culture strains were kept in BG11 and/or AMS1 media. Based on natural and culture material, 26 species were identified belonging to the families Chroococcaceae (2 taxa), Merismopediaceae (12), Microcystaceae (7) and Synechococcaceae (5). Among these species, six are potentialy toxic: Aphanocapsa incerta (Lemmerm.) Cronberg \& Komárek, Microcystis aeruginosa (Kütz.) Kütz., M. botrys Teiling, M. panniformis Komárek et al., M. wesenbergii (Komárek) Komárek, and Radiocystis fernandoi Komárek \& Komár.-Legn. Bacularia and Coelosphaeriopsis are genera reported for the first time in Brazil.
\end{abstract}

Key words - Brazil, Chroococcales, Cyanobacteria, plankton, taxonomy

RESUMO - (Cianobactérias planctônicas do Estado de São Paulo, Brasil: Chroococcales). Estudos de biodiversidade de cianobactérias planctônicas iniciaram-se em 1997 com intenso esquema de coletas em diferentes corpos d'água do Estado de São Paulo. Em virtude dos problemas gerados pela eutrofização e pelas frequentes florações de cianobactérias, as amostragens foram concentradas em reservatórios da região do Alto Tietê que fornecem água para milhões de pessoas. As amostras foram coletadas com rede de plâncton de $20 \mu \mathrm{m}$ de abertura de malha ou com Garrafa de Van Dorn. Parte de cada amostra foi preservada com formol ou lugol e parte foi isolada e mantida em cultura em meios BG11 e/ou AMS1. Com base no estudo de material de campo e de cultura, 26 espécies foram identificadas, pertencentes às famílias Chroococcaceae (2 taxons), Merismopediaceae (12), Microcystaceae (7) e Synechococcaceae (5). Dentre estas espécies, seis são potencialmente tóxicas: Aphanocapsa incerta (Lemmerm.) Cronberg \& Komárek, Microcystis aeruginosa (Kütz.) Kütz., M. botrys Teiling, M. panniformis Komárek et al., M. wesenbergii (Komárek) Komárek, e Radiocystis fernandoi Komárek \& Komár.-Legn. Bacularia e Coelosphaeriopsis são gêneros citados pela primeira vez para o Brasil.

Palavras-chave - Brasil, Chroococcales, Cyanobacteria, plâncton, taxonomia

\section{Introduction}

According to Komárek \& Anagnostidis (1999), the ordem Chroococcales comprises 11 families and around 90 genera, including unicellular and colonial forms. Generally, the typical planktic chroococcales are isopolar and present one, two or three planes of cell division. Therefore, this feature is one of the most important for separating the families of Chroococcales. Besides the planes of cell division, the correct observation of shapes and sizes of cells and colonies, the presence of aerotopes,

1. Instituto de Botânica, Seção de Ficologia, Caixa Postal 4005, 01061-970 São Paulo, SP, Brazil.

2. University of South Bohemia, Institute of Botany, Dukelská 135, CZ-37982 Trebon, Czech Republic.

3. Hydrobiological Institute AS CR, Na sádkách 7, CZ-37005 Ceské Budejovice, Czech Republic.

4. Corresponding author: celiasant@ig.com.br

$\dagger \quad$ In memoriam the features of the mucilaginous envelope and the type of environment are fundamental for characterizing the different groups of planktic Chroococcales.

Many species of cyanobacteria are well known as bloom formers and toxin producers in freshwaters all over the world, which are harmful to public health and environment (Carmichael 1996). Microcystis is the most common genus of Chroococcales in Brazil and $M$. aeruginosa is the most widespread species (Sant'Anna \& Azevedo 2000). In spite of that, many taxonomic problems of coccoid cyanobacteria remain unsolved and comparison between material from nature and culture are extremely useful.

The following papers are important contributions to the taxonomic studies of Brazilian Chroococcales: Senna \& Ferreira (1986), Werner (1988), De-La-Mora (1989), Franceschini (1992), Werner \& Rosa (1992), Senna (1994), Senna et al. (1999), Azevedo et al. (1999), Werner \& Sant'Anna (2000), and Werner (2002). 
Particularly to São Paulo State, the papers of Necchi \& Sant' Anna (1986), Azevedo (1991), Sant'Anna et al. (1991a, b), Komárek \& Komárková-Legnerová (1993), Azevedo \& Sant'Anna (1994a, b, 1999, 2003), Azevedo \& Kovácik (1996), Azevedo et al. (1996), Branco et al. (1996), Senna et al. (1998), Sant'Anna \& Azevedo (2000), and Komárek et al. (2002) provide usefull taxonomic information about these organisms.

The present paper was carried out based on field and culture material and aims to contribute to the taxonomic knowledge of coccoid cyanobacteria diversity in Brazil.

\section{Material and methods}

The samples were taken from different freshwater bodies of São Paulo State, mainly from "Alto Tietê" region because of the frequent cyanobacterial blooms that occur in the reservoirs of this area. The main reservoirs studied in the State of São Paulo were: Guarapiranga, Billings, Taiaçupeba, Jundiaí, Paraibuna, Barra Bonita, Americana, Jurumirim, Broa, Ponte Nova, Jaguari, Atibainha, Paiva Castro, and Cachoeira. We also collected samples from several artificial water bodies in the city of São Paulo and from rivers, streams and small lakes in the State of São Paulo.

Samples were collected using $20 \mu \mathrm{m}$ mash plankton net or Van Dorn's bottle. They were preserved with formaldehyde or lugol solution. The structure of mucilaginous envelope was observed using China Ink (J. Komárek, unpublished data). A total of 125 samples were studied and the most representative ones were selected and cited therein for each species.

Part of the samples was isolated in unialgal cultures and kept in BG-11 and/or AMS-1 media. The culture conditions were: temperature $22 \pm 1^{\circ} \mathrm{C}$, irradiances $15-20 \mu \mathrm{mol} \cdot \mathrm{m}^{-2} \cdot \mathrm{s}^{-1}$ and 14-10h light-dark cycle (Azevedo \& Sant'Anna 2003). All the culture strains studied (table 1) belong to the Institute of Botany Algae Culture Collection (SPC). The classification system of Komárek \& Anagnostidis (1999) was adopted.

\section{Results and Discussion}

\section{Chroococcaceae}

Chroococcus dispersus (Keissl.) Lemmerm., Ark. Bot. 2:102. 1904.

Basionym: Chroococcus minor (Kütz.) Nägeli var. dispersus Keissl., Verh. zool.-bot. Ges. Wien 52:311. 1902.

Figure 1.

Colonies microscopic, usually 4-16 celled, with cells gathered irregularly in free groups in the center; mucilage fine, hyaline, colorless, diffuse, forming an indistinct, wide margin around the cells; cells spherical, pale bluegreen, 4-4.6 $\mu \mathrm{m}$ in diameter; cell content blue-green, homogenous, without aerotopes.

Selected material: BRAZIL: São PAULo: Valinhos, lake, 2-X-1991, C.L. Sant'Anna et al. s.n. (SP355897).

Chroococcus dispersus belongs to the group of planktic Chroococcus species, classified into the subg. Limnococcus. They are distributed over the world, but their diversity and the distribution of various morphotypes are little known. They are usually identified basically according to cell size. The taxonomy of tropical populations is commonly unclear; therefore all data about these populations are useful. Although this species is very rarely recorded from tropical regions, we found a population that corresponds very well to the original description of $C$. dispersus (figure 1 shows the characteristic cells disposition in group).

Table 1. Culture strains from the Institute of Botany Culture Collection (SPC) analyzed in this study.

\begin{tabular}{lcl}
\hline Species & Strain & Origin \\
\hline Aphanothece conglomerata & 515 & Atibainha Reservoir \\
Coelosphaerium evidenter-marginatum & 030 & Garças Lake \\
Merismopedia tenuissima & 691 & Garças Lake \\
Microcystis aeruginosa & 760 & Taiaçupeba Reservoir \\
Microcystis botrys & 758 & Taiaçupeba Reservoir \\
Microcystis novacekii & 503 & Billings Reservoir \\
Microcystis panniformis & 686 & Garças Lake \\
Microcystis protocystis & 698,522 & Guarapiranga and Americana Reservoirs \\
Radiocystis fernandoi & 736 & Rio Corumbataí \\
Sphaerocavum brasiliense & 484 & Billings Reservoir \\
\hline
\end{tabular}


Chroococcus distans (G.M. Sm.) Komárk.-Legn. \& Cronberg, Algol. Studies 72:26. 1994.

Basionym: Chroococcus limneticus Lemmerm. var. distans G.M. Sm., Bull. Torrey Bot. Cl. 43:481. 1916. Figure 2.

Colonies free-floating, with wide, homogeneous, fine mucilage, slightly diffuse at the margin; cells irregularly situated in the colonial center, slightly distant one from another, spherical or hemispherical after division, 5.4-7.4 $\mu \mathrm{m}$ in diameter; cell content blue-green, more or less homogeneous, without aerotopes.

Selected material: BRAZIL: São PAULO: São Paulo, lake in Ibirapuera Park, 14-X-1996, M.T.P. Azevedo s.n. (SP355898).

Chroococcus distans is another well characterized type of planktic Chroococcus species (subg. Limnococcus), common in large eutrophic reservoirs in São Paulo State. It was usually classified as a variety of $C$. limneticus, which mostly differs by larger cells. Besides, C. limneticus presents individual mucilaginous envelope around the cells that is lacking in $C$. distans (Komárková-Legnerová \& Cronberg 1994, Komárek \& Anagnostidis 1999). We have never found typical C. limneticus in our samples, but it was been cited several times in floristic studies from Brazil (Werner 1988, Sant'Anna et al. 1988, Senna 1992). In contrast, C. distans (or C. limneticus var. distans) was not yet registered. Because of the typical $C$. limneticus (considered as cosmopolitan) is common mainly in large lakes in temperate zones up to subpolar areas, studies about the distribution of both mentioned species would be very interesting. Probably, both species are present in Brazilian lentic water bodies, and further studies about their taxonomic delimitation and ecology would be surely important.

\section{Merismopediaceae}

Aphanocapsa delicatissima W. West \& G.S. West, J. Linn. Soc. Bot. 40:431. 1912.

Figure 13.

Colonies rounded, elongated, or irregular, not clatrate; mucilage hyaline, diffluent; cells spherical, loosely agregated, $0.8-1 \mu \mathrm{m}$ in diameter; cell content blue-green, homogeneous, without aerotopes.

Selected material: BRAZIL: SÃo PAULO: Paraibuna Reservoir, 6-XI-1996, J. Komárek s.n. (SP355896).

Aphanocapsa elachista W. West \& G.S. West, Journ. Linn. Soc. 30:276. 1894.

Figure 3.
Colonies irregular, diffuse, microscopic up to large, lobate and about $1 \mathrm{~mm}$ in diameter (in massive developments); mucilage fine, colorless, hyaline, indistinct; cells sparse, irregularly distributed, spherical, becoming hemispherical after division, 1.8-2(2.4) $\mu \mathrm{m}$ in diameter; cell content pale blue-green, without aerotopes.

Selected material: BRAZIL: SÃo Paulo: Paiva Castro Reservoir, 29-I-1991, C.L. Sant'Anna s.n. (SP355902); Americana Reservoir, 18-X-1995, M.C. Carvalho s.n. (SP355903).

The taxonomy of planktic Aphanocapsa species is still unclear. The very simple cell morphology does not enable to distinguish various taxa. Planktic colonies occur in freshwater reservoirs over the world, and the identification of different morphotypes from distant regions is difficult. The group of planktic species, comprising cells of $0.5-2 \mu \mathrm{m}$ in diameter, represents the particularly difficult cluster of types, which differ only by cell density (with certain variation range) and by the way of cells organization in colony. The study of these species is difficult also because the mentioned features often disappear under culture conditions. Two types with sparsely distributed cells in mucilaginous, diffuse microscopic colonies and with cells $0.5-2 \mu \mathrm{m}$ in diameter were described by W. West and G.S. West: A. delicatissima with cells $0.5-2 \mu \mathrm{m}$ in diameter and A. elachista with cells 1.3-2(2.4) $\mu \mathrm{m}$ in diameter. The first one has probably cosmopolitan distribution, but it is recorded previously from temperate zones. The second one (A. elachista) is considered as predominantly tropical and many of our samples from eutrophic reservoirs of central part of São Paulo State correspond better to the original description of this species (cells always greater than $1.5 \mu \mathrm{m}$ in diameter).

Aphanocapsa holsatica (Lemmerm.) Cronberg \& Komárek, Algol. Studies 75:327. 1994.

Basionym: Chlatrocystis holsatica Lemmerm., Forschungsber. biol. Stat. Plön 10:150. 1903.

Figure 5.

Colonies rounded when young, later lobate, elongated, clatrate, with cells densely arranged; mucilage hyaline, diffluent; cells spherical, 1-1.5 $\mu \mathrm{m}$ in diameter; cell content blue-green, homogeneous, without aerotopes.

Selected material: BRAZIL: São PAulo: Americana Reservoir, 18-X-1995, M.C. Carvalho s.n. (SP355903). 


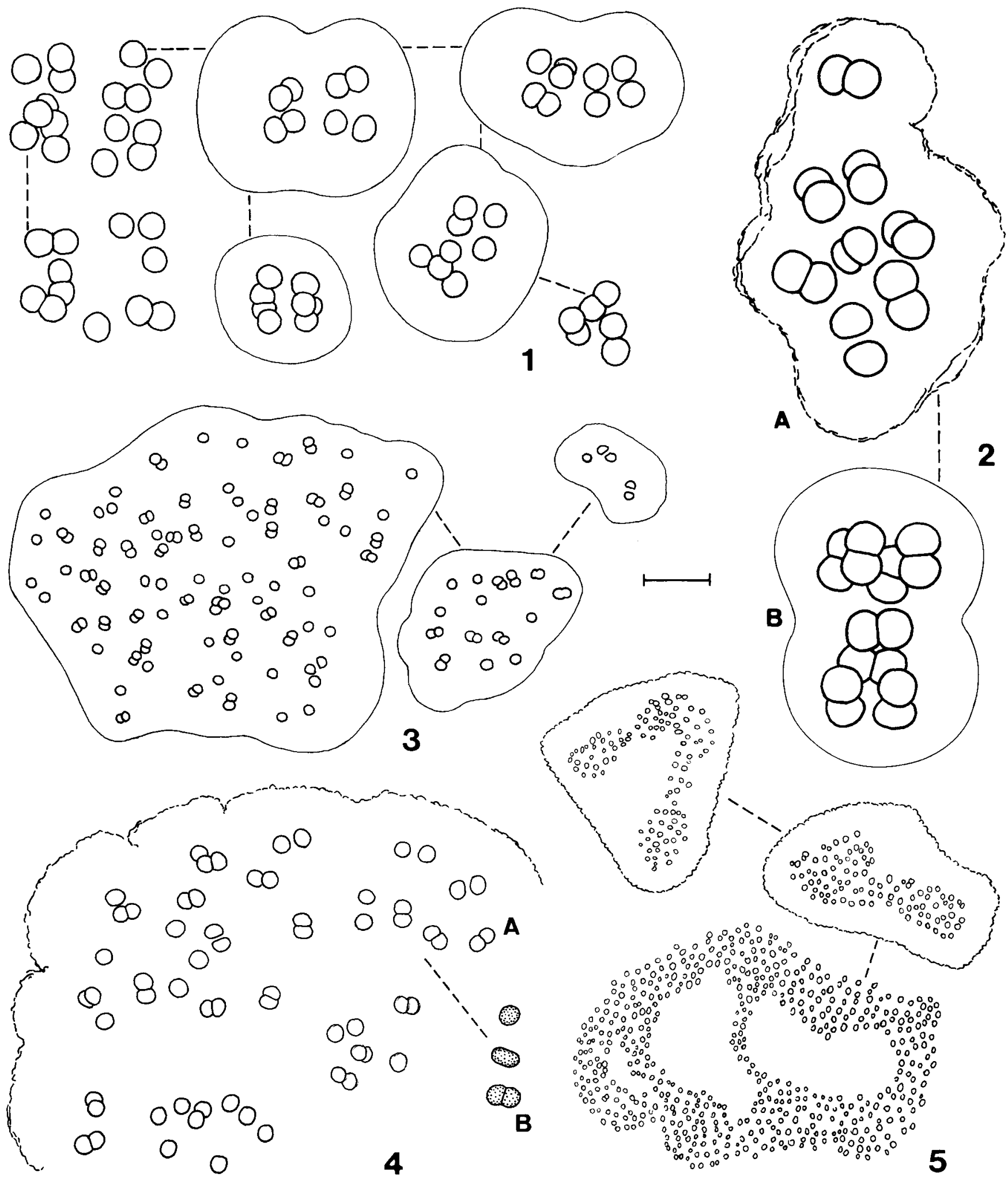

Figures 1-5. Chroococcales species from São Paulo State. 1. Chroococcus dispersus: various forms of colonies. 2. C. distans: adult colony (A), young colony showing the cells still aggregated (B). 3. Aphanocapsa elachista: colonies of different age. 4. A. koordersii: part of a large colony (A) and detail of cell content (B). 5. A. holsatica: different forms of colony. Bar $=10 \mu \mathrm{m}$. 
Aphanocapsa incerta (Lemmerm.) Cronberg \& Komárek, Algol. Studies 75:327. 1994.

Basionym: Polycystis incerta Lemmerm., Forschungsber. biol. Stat. Plön 7:132. 1899.

Figure 14.

Colonies rounded or elongated with cells densely agregated in the central part; mucilage hyaline, diffluent; cells spherical, $1.5-3 \mu \mathrm{m}$ in diameter; cell content bluegreen, granulated, without aerotopes.

Selected material: BRAZIL: SÃo PAULO: Cachoeira Reservoir, 15-II-1996, M.C. Carvalho s.n. (SP355904); São Paulo, Garças Lake, 27-V-1992, C.L. Sant'Anna s.n. (SP355905).

Aphanocapsa koordersii Ström, Nyt. Mag. Naturv. 61:128. 1923.

Figure 4.

Colonies microscopic, slimy, with more or less evenly, but irregularly and sparsely distributed cells; mucilage fine, diffuse, homogeneous, colorless; cells spherical, after division hemispherical, 2-3 $\mu \mathrm{m}$ in diameter; cell content pale blue-green, without aerotopes.

Selected material: BRAZIL: São PAULO: Billings (Taquacetuba) Reservoir, 22-XI-2000, M.C. Carvalho s.n. (SP355906); Paiva Castro Reservoir, 19-II-1991, C.L. Sant'Anna s.n. (SP355901).

Aphanocapsa koordersi belongs to the group of planktic Aphanocapsa species with microscopic colonies and more or less sparsely distributed cells within very fine, diffuse, colorless slime. The difference from A. elachista is only in cell size. It is very similar also to other described species as A. conferta (W. West \& G.S. West) Komárková-Legnerová \& Cronberg and A. planctonica (G.M. Smith) Komárek \& Anagnostidis, and it is commonly misinterpreted with both these species. The only separation of A. koordersi is the ecology and the occurrence in warm, tropical and subtropical reservoirs, while $A$. conferta and A. planctonica are known and identified from temperate Nordic ponds, lakes and larger reservoirs. If they all belong to one genotype, it must be proved by molecular methods in the future.

Coelosphaerium evidenter-marginatum M.T.P. Azevedo \& C.L. Sant'Anna, Algol. Studies 94:36. 1999. Figure 20.

Colonies microscopic, rounded when young (30-52 $\mu \mathrm{m}$ in diameter), irregular when adult (until $250 \mu \mathrm{m}$ length), sometimes forming composed colonies; mucilage hyaline, inconspicuous; cells spherical, sometimes ligthly ovoid, regularly distributed on the colony surface, 2.2-3 $\mu \mathrm{m}$ in diameter; cell content bluegreen, homogeneous, without aerotopes.

Selected material: BRAZIL: São PAULo: São Paulo, Garças Lake, 12-XII-1996, C.L. Sant'Anna s.n. (SP355908); Billings (Taquacetuba) Reservoir, 22-XI-2000, M.C. Carvalho s.n. (SP355906).

Coelomoron cf. tropicale Senna et al. Nova Hedwigia 67:96. 1998.

Figures 11, 33.

Colonies spherical, oval or composed of hemispherical subcolonies, usually $20-28 \mu \mathrm{m}$ in diameter, with generally dense aggregated cells in the peripheral layer; cells obovoid, radially arranged, 1.4-3 $\mu \mathrm{m}$ length, 1.4-2.8 $\mu \mathrm{m}$ in diameter; cell content blue-green, without aerotopes.

Selected material: BRAZIL: São PAULo: Cachoeira Reservoir, 15-II-1996, M.C. Carvalho s.n. (SP355904); Paiva Castro Reservoir, 29-I-1991, C.L. Sant'Anna s.n. (SP355902).

Coelomorum tropicale was describe as C. tropicalis but according to International Code of Botanical Nomenclature this name is not correct because Coelomorum is a neutral name and the specific epithet must be in conformity with it. Therefore, the correct name is $C$. tropicale as already used by Komárek \& Anagnostidis (1999).

From six described Coelomoron species, four are known from American tropical or subtropical regions. According to Komárek (1989) and Senna et al. (1998), Coelomoron is a very diversified genus in these regions. C. tropicale was described from São Paulo State which was found in several localities and where it seems to be commonly distributed. Recently, it has been found also in South Africa (Komárek \& Cronberg 2001). During our studies of cyanobacterial flora from São Paulo State, in addition to the planktic forms, we found metaphytic populations of a Coelomoron type, ecologically and morphologically similar to $C$. tropicale, but differing by the larger colonies, the more obovoid cells and by the higher number of cells in the colonies. As described by Senna et al. (1998), we also found colonies exhibiting different stages of cell agregation. The identity with C. tropicale is probable, but should be confirmed in future. Apparently several taxonomically not evaluated populations from Cuba (Komárek 1989) belong to this type. 


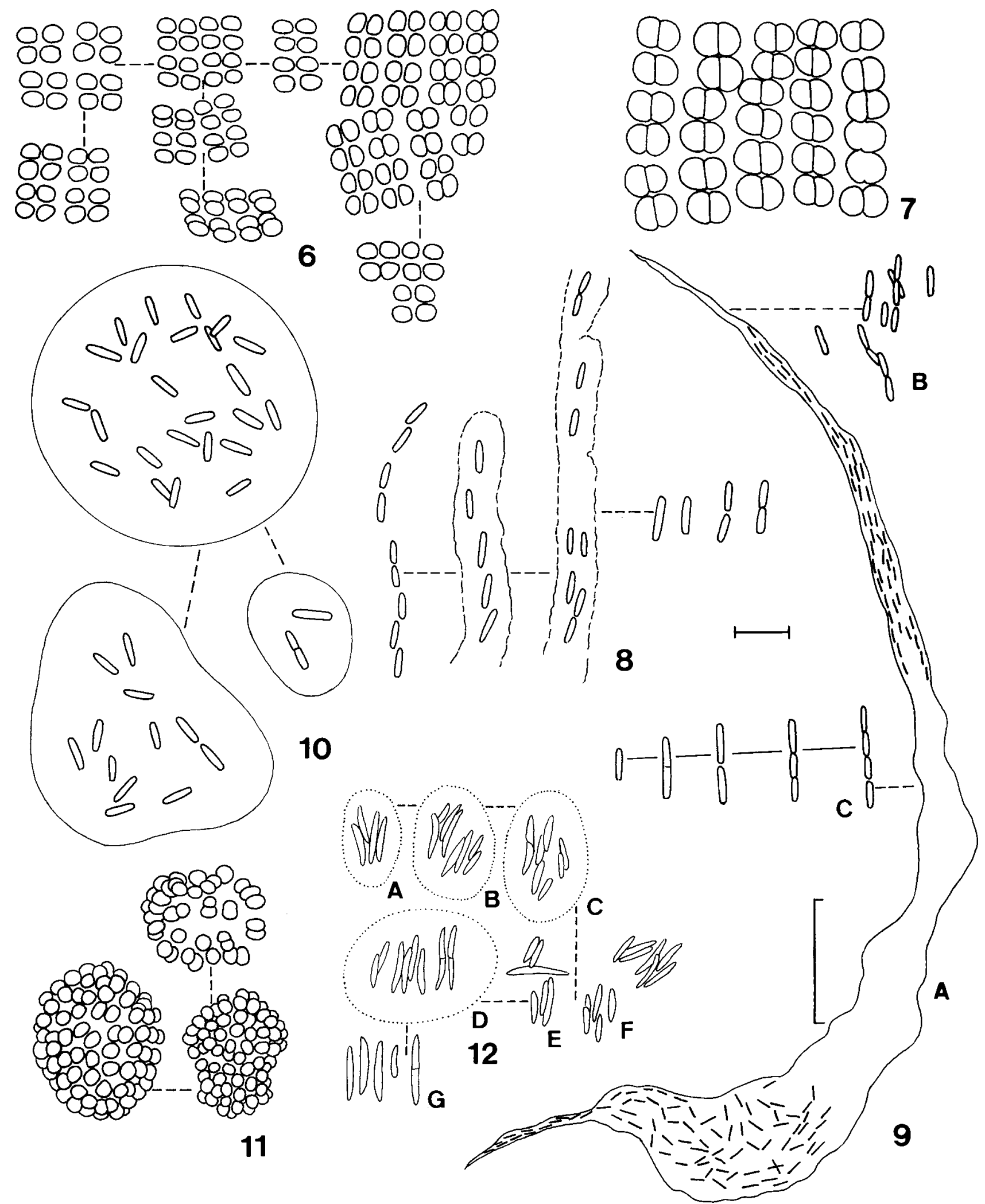

Figures 6-12. Chroococcales species from São Paulo State. 6. Merismopedia punctata. 7. M. glauca. 8-9. Bacularia gracilis. 8. Metaphytic population showing tube-like colony with rounded end. 9. General aspect of colony with typical pointed closed ends (A), details of cells (B), scheme of cell division (C). 10. Rhabdoderma lineare. 11. Coelomoron cf. tropicale: colonies with different stages of cell agregation. 12. Rhabdoderma ellipsoidea: variability of colonies (A-G). Bars = $10 \mu \mathrm{m}(6-8,9 \mathrm{~B}, \mathrm{C}, 10-12)$, $50 \mu \mathrm{m}(9 \mathrm{~A})$. 
Coelosphaeriopsis sp.

Figure 19.

Colonies rounded, hollow, formed by cells disposed peripherically, $40-50 \mu \mathrm{m}$ in diameter; mucilage hyaline around each cell; cells rounded, without individual mucilaginous envelope 3-4 $\mu \mathrm{m}$ in diameter, with individual mucilaginous envelope 5-6 $\mu \mathrm{m}$ in diameter; cell content blue-green, without aerotopes.

Selected material: BRAZIL: São PAULo: Paiva Castro Reservoir, 28-IX-1998, C.L. Sant'Anna \& M.T.P. Azevedo s.n. (SP355965).

This genus is firstly referred to Brazil; it differs from Coelosphaerium by the individual mucilaginous envelope around each cell. The only tropical species, C. halophila (Lemmermann) Geitler occurs in salty ponds in the Pacific Islands. There is also one species in freshwater environments, $C$. chlamydocystis Skuja, which is restricted to lakes from Sweden and presents smaller cells (without sheath 1.7-2.5 $\mu \mathrm{m}$ diam.) than the Brazilian material. As we found just a small population, it was not possible to determine the real taxonomic delimitation of these specimens.

Merismopedia glauca (Ehrenb.) Kütz., Phycol. Germ. p.42. 1845.

Basionym: Gonium glaucum Ehrenb., Infunsions p.58. 1845.

Figure 7.

Colonies microscopic, plate-like, squarish, composed mainly by 32-64 cells disposed in parallel rows; mucilage hyaline, diffluent; cells rounded, becoming hemispherical after division, 3-5 $\mu \mathrm{m}$ in diameter; cell content blue-green, without aerotopes.

Selected material: BRAZIL: São PAULO: Jacareí Reservoir, 10-X-1996, Komárek et al. s.n. (SP355909).

Merismopedia punctata Meyen, Neues Syst. Pfl.Physiol. 3:440. 1839.

Figure 6.

Colonies microscopic, plate-like, composed by 8-64 cells disposed in rows; mucilage hyaline, diffluent; cells spherical to slightly oval, becoming hemispherical after division, (1.8)2.3-3 $\mu \mathrm{m}$ in diameter; cell content bluegreen, without aerotopes.

Selected material: BRAZIL: São PAULO: Ibirá, lake, 5-IX-1998, C.L. Sant'Anna s.n. (SP355900); Billings (Taiaçupeba) Reservoir, 22-XI-2000, M.C. Carvalho s.n. (SP355906).

Merismopedia punctata is a common species, but sometimes misinterpreted, particularly with $M$. hyalina
(Ehrenberg) Kützing or M. glauca (Ehrenberg) Kützing. The closest species, M. hyalina, differs from $M$. punctata by the smaller number of cells in the colony (generally until 16) and by the somewhat irregular cells disposition. M. punctata presents colonies regularly table-like, generally with 16 to 32 cells. Because this species is common in tropical and subtropical regions, but often neglected, we described one typical population of this species from one clear pond with numerous aquatic plants.

Merismopedia tenuissima Lemmerm., Bot. Zbl. 76:154. 1898.

Figure 21.

Colonies plate-like, squarish, formed by 8-32 cells; mucilage hyaline, diffluent; cells rounded, becoming hemispherical after division, 1.5-2 $\mu \mathrm{m}$ in diameter; cell content blue-green, without aerotopes.

Selected material: BRAZIL: São PAULO: São Paulo, Garças Lake, 12-XII-1996, C.L. Sant'Anna s.n. (SP355908); Cachoeira Reservoir, 15-II-1996, M.C. Carvalho s.n. (SP355904); stabilization pond near Atibainha Reservoir, 16-X-1996, J. Komárek s.n. (SP355958).

Merismopedia tenuissima is very common in planktic communities and it is more frequent in eutrophic freshwaters, but occasionally it can be also found in brackish waters. On account of the small size of its cells, the samples should be carefully examined or the colonies of M. tenuissima will be easely over looked.

Sphaerocavum brasiliense M.T.P. Azevedo \& C.L. Sant'Anna, Algol. Studies 109:81. 2003.

Figures 15-18.

Colonies hollow, spherical when young, later becoming elongated or irregular; mucilage hyaline, indistinct; cells rounded, 2.4-3.6 $\mu \mathrm{m}$ in diameter, disposed at colonial surface; cell content blue-green, with aerotopes.

Selected material: BRAZIL: SÃo PAULO: São Paulo, lake in club, 2-VI-1999, C.L. Sant'Anna s.n. (SP336724, SP355893); Billings Reservoir, 22-V-1998, C.L. Sant'Anna s.n. (SP336725).

Sphaerocavum is a tropical and subtropical genus recently proposed by Azevedo \& Sant'Anna (2003), occurring in eutrophic freshwaters of São Paulo State and also from Uruguai. S. brasiliense forms heavy blooms during the spring and summer and could be misinterpreted with Microcystis species. The main difference between both genera is the hollow colonies 

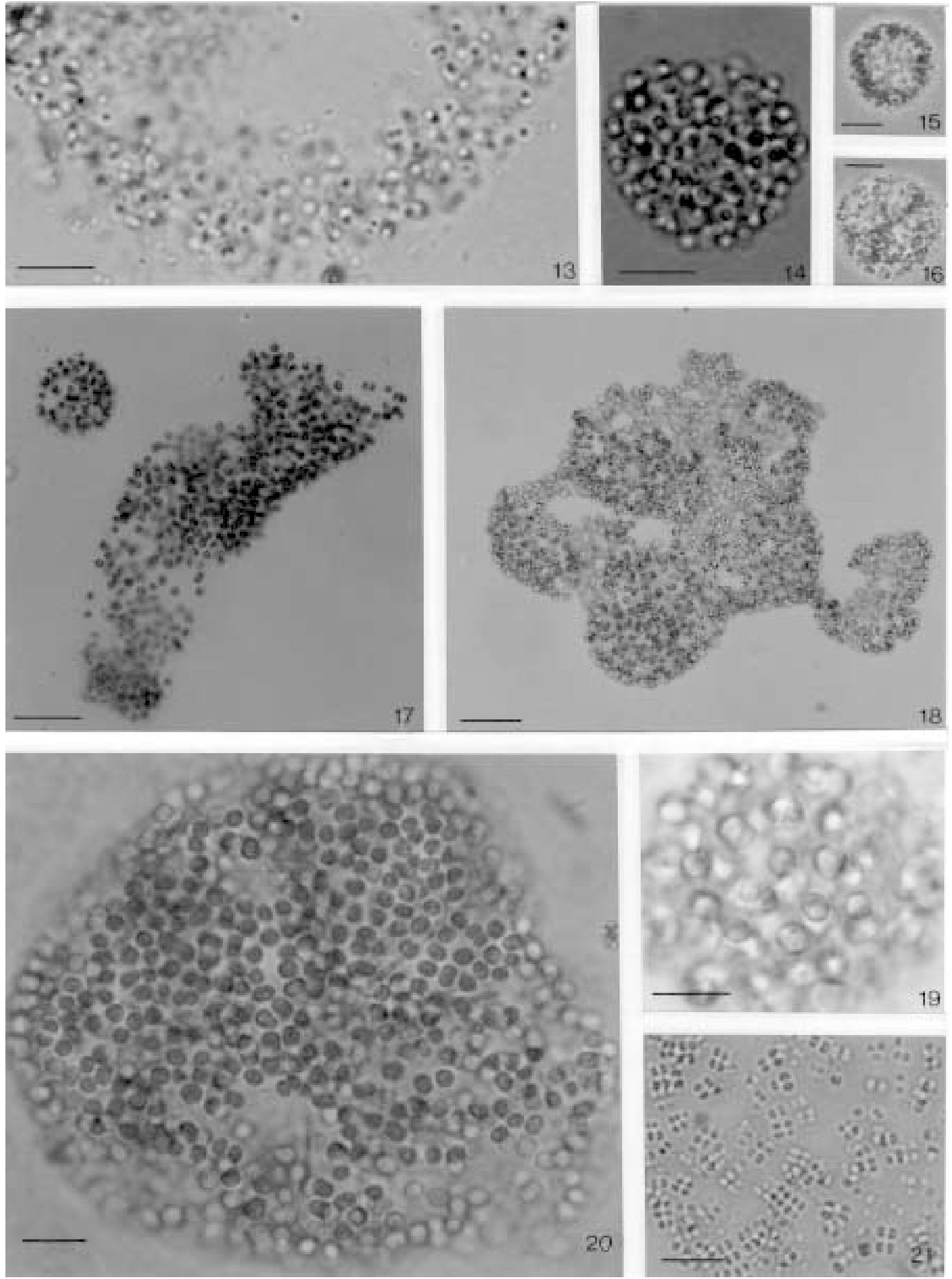

Figures 13-21. Chroococcales species from São Paulo State. 13. Aphanocapsa delicatissima. 14. A. incerta. 15-18. Sphaerocavum brasiliense. 15-16. Material from culture showing colonies in different stages of development. 17-18. Material from nature. 19. Coelosphaeriopsis sp. 20. Coelosphaerium evidenter-marginatum (material from culture, according to Azevedo \& Sant'Anna 2000). 21. Merismopedia tenuissima (material from culture). Bars $=10 \mu \mathrm{m}(13,14,17-21), 5 \mu \mathrm{m}(15,16)$. 
of Sphaerocavum as a consequence of cell division in two planes. Microcystis presents compact colonies and cell division in three planes. Bioassay with mice indicated that the tested population of $S$. brasiliense is not toxic (Azevedo \& Sant'Anna 2003).

Microcystaceae

Microcystis aeruginosa (Kütz.) Kütz., Tab. Phycol. 1:6. 1846.

Basionym: Micraloa aeruginosa Kütz., Linnaea 8:371. 1833.

Figures 22, 30C.

Colonies micro or macroscopic, rounded when young, becoming elongated, irregular or lobate when adult, sometimes clathrate; mucilage hyaline, diffluent, forming a wide margin around group of cells; cells spherical, 4-6.5 $\mu \mathrm{m}$ in diameter; cell content dark green, with aerotopes.

Selected material: BRAZIL: SÃo PAULO, lake in club, 2-VI-1999, C.L. Sant'Anna s.n. (SP336724, SP355893); Guarapiranga Reservoir, 21-VIII-2001, C.L. Sant'Anna s.n. (SP355910); São Paulo, Garças Lake, 27-V-1992, C.L. Sant'Anna s.n. (SP55905); SP123, Km 22, lake, 9-XI-2002, M.T.P. Azevedo et al. s.n. (SP355911).

Microcystis aeruginosa is the widest spread species in Brazil, occurring from the North to the South of the country (Sant'Anna \& Azevedo 2000). In eutrophic stratified freshwaters, $M$. aeruginosa is the chrooccocales more frequent in cyanobacterial blooms and, even when occurring together with other species, it is often the dominant species. In relation to the wide distribution of $M$. aeruginosa, it is necessary to take into account the mistakes in its identification, mainly when the planes of cell division are misunderstood. Microcystis colonies are compact, sometimes clatrate but never hollow, that is, with one single layer of cells at the colony perifery. The compact colonies of Microcystis come from three planes of cell division, typical of this genus and must be carefully observed to avoid misinterpretation with species of Radiocystis, Coelosphaerium, Pannus and Sphaerocavum.

Microcystis botrys Teiling, Bot. Notiser 1942:65. 1942. Figures 24-25.

Colonies microscopic, rounded or elongated, frequently forming packets, not clathrate; mucilage hyaline, diffluent, wide, forming radially oriented protuberances around groups of cells; cells spherical,
(3)5-6 $\mu \mathrm{m}$ in diameter; cell content blue-green, with aerotopes.

Selected material: BRAZIL: São PAULO: Americana Reservoir, 24-I-2003, T.C. Mercante s.n. (SP355956).

Microcystis botrys is a little known species and frequently misinterpreted with $M$. aeruginosa. It should be much more widespread in Brazil than recorded in the literature. The mucilage with radially oriented protuberances is the basic feature to distinguish it from $M$. aeruginosa. This feature remains stable also in culture and must be carefully observed using stains like China Ink.

Microcystis novacekii (Komárek) Compère, Bull. Jard. Bot. Nat. Belg. 44:19. 1974.

Basionym: Diplocystis novacekii Komárek in Komárek \& Ettl, Algol. Stud., p.63. 1958.

Figure 23.

Colonies microscopic, rounded, elongated or lenticular, forming packets of cells in the central part of colony and generally with sparce cells on the colony perifery, not clathrate; mucilage hyaline, firm, wide; cells spherical, 3-5.5 $\mu \mathrm{m}$ in diameter; cell content blue-green, with aerotopes.

Selected material: BRAZIL: SÃo PAULO: Cachoeira Reservoir, 15-II-1996, M.C. Carvalho s.n. (SP355904).

Microcystis panniformis Komárek et al., Cryptogamie, Algol. 23:165. 2002.

Figures 31, 30B.

Colonies micro or macroscopic, initially irregular, later becoming rounded or elongated, with cells densely aggregated in all the mucilage surface, not clathrate; mucilage hyaline, inconspicuous; cells spherical, 3-4 $\mu \mathrm{m}$ in diameter; cell content brownish green, with aerotopes.

Selected material: BRAZIL: São Paulo: São Paulo, lake in club, 2-VI-1999, C.L. Sant'Anna s.n. (SP3360724, SP355893); São Paulo, lake in Ibirapuera Park, 6-X-1996, M.T.P. Azevedo s.n. (SP55896); Represa Billings, 22-V-1998, C.L. Sant'Anna s.n. (SP336725); Pindamonhangaba, fish pond, 20-VI-1995, Z. Beyruth s.n. (SP355962); Americana Reservoir, 24-I-2003, T.C. Mercante s.n. (SP355956).

Microcystis panniformis is a common species in planktic communities of eutrophic ponds, lakes and reservoirs, frequently forming blooms together with M. aeruginosa. It was recently described (Komárek et al. 2002) and before that M. panniformis was probably identified as M. aeruginosa. The main feature 
of this species is the dense distribution of cells in all the mucilage surface (there is no wide mucilaginous envelope as in $M$. aeruginosa). According to Komárek et al. (2002), M. panniformis was found also together with other cyanobacterias in the water of Tabocas Reservoir (Caruaru, Pernambuco State, northeastern Brazil) that was associated to the Cararuaru tragedy in 1996 (Jokinsen et al. 1998).
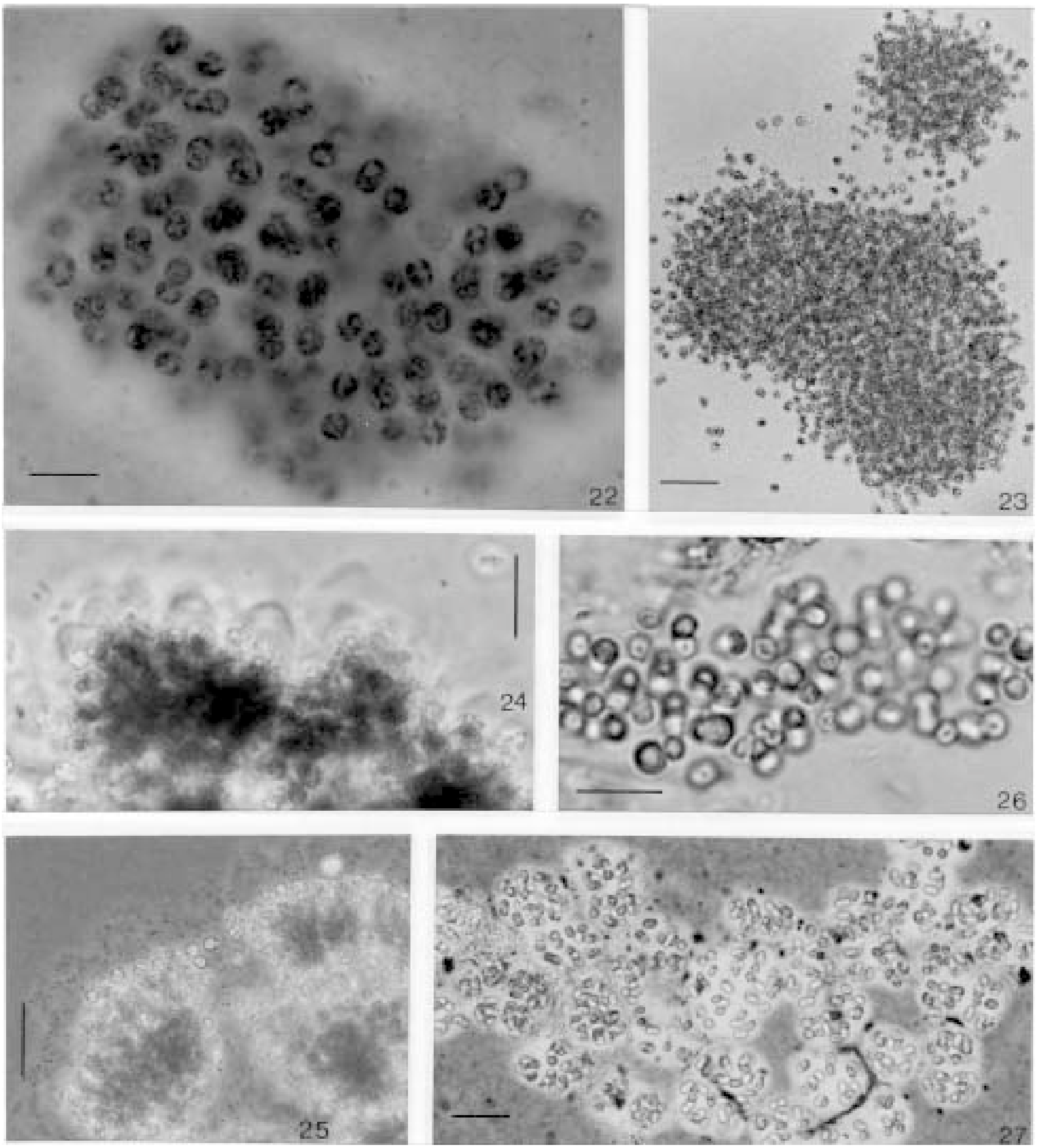

Figures 22-27. Chroococcales species from São Paulo State. 22. Microcystis aeruginosa. 23. M. novacekii (material from culture). 24-25. M. botrys. 24. Detail of mucilage protuberances. 25. General aspect of part of a colony. 26. Microcystis sp.: cells with one central aerotope. 27. Aphanothece conglomerata (material from culture). Bars $=10 \mu \mathrm{m}(22,25,26), 20 \mu \mathrm{m}(23$, 24,27). 
Microcystis protocystis Crow, New Phytol. 22:62. 1923. Figures 28-29, 30A.

Colonies microscopic, irregular, with scattered cell distribution in the mucilage surface, not clathrate; mucilage hyaline, diffluent; cells spherical, with individual mucilaginous envelope, 4-6 $\mu \mathrm{m}$ in diameter; cell content bluegreen, with aerotopes.

Selected material: BRAZIL: São PaUlo: São Paulo, lake in club, 2-VI-1999, C.L. Sant'Anna s.n. (SP336724); Represa Billings, 22-V-1998, C.L. Sant'Anna s.n. (SP336725); Guarapiranga Reservoir, 21-VIII-2001, C.L. Sant'Anna s.n. (SP355910); Americana Reservoir, 24-I-2003, T.C. Mercante s.n. (SP355956).

The mucilaginous envelope around each cell makes Microcystis protocystis different from all other Microcystis species and it is easely observed using China Ink stain. Besides, the cells are much more sparsely distributed in the diffluent mucilage than in the other species. This sparse cell disposition gives $M$. protocystis the aspect of old or senescent colonies of different Microcystis species. For this reason, M. protocystis distribution should be wider than normally refered in the literature.

Microcystis wesenbergii (Komárek) Komárek in Kondrateva, Cvetenie vody, p.13. 1968.

Basionym: Diplocystis wesenbergii Komárek in Komárek \& Ettl, Algol. Stud., p.68. 1958.

Figure 32.

Colonies micro or macroscopic, rounded, elongated or lobate, frequently clathrate; mucilage hyaline, firm, not difluent, well delimited, with refractive outline; cells spherical, 4-6 $\mu \mathrm{m}$ in diameter; cell content blue-green, with aerotopes.

Selected material: BRAZIL: São PaULo: São Paulo, lake in club, 2-VI-1999, C.L. Sant'Anna s.n. (SP336724); São Paulo, lake in Ibirapuera Park, 6-X-1996, M.T.P. Azevedo s.n. (SP55896).

Microcystis sp.

Figure 26.

Colonies microscopic, rounded or elongated, with cells loosely disposed in the mucilage surface, not clathrate; mucilage hyaline, diffluent, wide; cells spherical, 2.5-3 $\mu \mathrm{m}$ in diameter; cell content blue-green, with one central aerotope.

Selected material: BRAZIL: SÃo PAULO: Paraibuna Reservoir, 6-XI-1996, J. Komárek et al. s.n. (SP355896).
The studied material is similar to Microcystis natans Lemmerm. ex Skuja, but this species presents cells with mean diameter of $1.5 \mu \mathrm{m}$, besides it is restricted to temperate regions. As we found only a small population, it was not possible to confirm these metric differences, but it is important to register the variability inside the complex genus Microcystis.

\section{Synechococcaceae}

Aphanothece conglomerata F. Rich, Trans. R. Soc. S. Afr. 20:185. 1932.

Figure 27.

Colonies microscopic, initially rounded, later becoming elongated, irregular or composed when adults, with cells loosely distributed in the central part of colony; mucilage hyaline, conspicuous; cells widely oblong, 3.7-4 $\mu \mathrm{m}$ length, $2-2.5 \mu \mathrm{m}$ in diameter; cell content bluegreen, granulated, with aerotopes.

Selected material: BRAZIL: SÃo PAULO: Atibainha Reservoir, 19-IV-1997, C.L. Sant'Anna s.n. (SP355959).

Bacularia gracilis Komárek, Folia Geobot. Phytotax. 30:86. 1995.

Figures 8-9.

Colonies tube-like, formed by cells disposed more or less in parallel lines along the mucilaginous envelope; mucilage hyaline, close at the ends; cells rod-like with rounded ends, 6-8 $\mu \mathrm{m}$ length, $0.8-1.2 \mu \mathrm{m}$ in diameter; cell content pale blue-green, homogeneous, without aerotopes.

Selected material: BRAZIL: São PAULO: Ibirá, lake, 5-IX-1998, C.L. Sant'Anna s.n. (SP355900).

In spite of being mainly metaphytic, it is important to describe $B$. gracilis because the genus Bacularia is rare and completely unknown in Brazil. Besides, the great interface methaphyton/phytoplankton usually makes it possible to find metaphytic species in the plankton. The interesting genus Bacularia contains cyanobacteria with rod-like cells, which are arranged separately, but more or less in rows or in one direction in elongated tube-like mucilaginous formation. It is related to the genera Synechococcus and Rhabdoderma and the three probably have the same cell structure, but differing phenotypically mainly by the special form of colonies, indicating the different life strategy. The genus comprises five species: two are known from hot and mineral springs, one is marine, one was described from lakes and swamps in Siberia, and 
one, $B$. gracilis, was discovered in metaphyton of slightly alkaline lakes in Cuba (Komárek 1995). The Brazilian populations occur in similar biotopes and the form of colonies is quite similar to Cuban specimens, only the cell size is more variable. All other characters correspond to the original description, particularly the characters of colonies. Based on the transitional forms existing in the studied populations, we consider all these types as forms inside the variation range of the same species. Studies of the variability and distribution of B. gracilis are expectable.

Radiocystis fernandoi Komárek \& Komárk.-Legn., Preslia 65:357. 1993.

Figures 34-35B.

Colonies rounded or irregular, formed by one or several groups of cells disposed more or less in rows radially arranged from the center to the perifery; mucilage hyaline, envolving all groups of cells; cells rounded, 6-8.5 $\mu \mathrm{m}$ in diameter; cell content dark bluegreen, with aerotopes.

Selected material: BRAZIL: São PAULO: São Paulo, lake in Ibirapuera Park, 6-X-1996, M.T.P. Azevedo s.n. (SP55896); lake in Arujá, 27-XII-1996, M.C. Carvalho s.n. (SP355960); São Paulo, lake in Zoological Garden, 7-X-1996, J. Komárková-Legnerová s.n. (SP355961); Guarapiranga Reservoir, 21-VIII-2001, C.L. Sant'Anna s.n. (SP355910).

Rhabdoderma lineare Schmidler \& Lauterborn, Ber. dt. Bot. Ges. 18:149. 1900.

Figure 10.

Colonies rounded or elongated, with cells disposed more or less in line; mucilage hyaline, firm; cells cylindrical with rounded ends, straight, 3.2-6 $\mu \mathrm{m}$ length, 1-1.8 $\mu \mathrm{m}$ in diameter; cell content blue-green, with aerotopes.

Selected material: BRAZIL: São PAULO: São Paulo, Garças Lake, 27-IX-1996, C.L. Sant'Anna \& J. Komárková-Legnerová s.n. (SP355963).

Rhabdogloea ellipsoidea Schroed., Ber. dt. Bot. Ges. 35:549. 1917.

Figure 12.

Colonies elliptical or irregular, with cells disposed paralelly; mucilage hyaline, diffluent; cells spindle-like, lightly curved or sigmoid, 3.8-9.2 $\mu \mathrm{m}$ lenght, $1.2-2 \mu \mathrm{m}$ in diameter; cell content pale blue-green, without aerotopes.
Selected material: BRAZIL: São PAULO: Cachoeira Reservoir, 13-IX-1996, J. Komárek et al. s.n. (SP355964).

The genus Rhabdogloea is characterized by spindle-like cells enveloped by fine mucilage and by division only through crosswise binary fission. The cells are, in several species, oriented more or less in one direction within the colony. This genus comprises about 10 well-defined species, but its diversity is wider particularly in tropical regions. One still unsolved problem is the separation of the two most common species R. smithii (R. Chodat \& F. Chodat) Komárek and $R$. ellipsoidea. The latter is the type species of the genus. Both species are morphologicaly very similar, but they differ intensely by their ecology and distribution. $R$. smithii is known mainly from plankton of large, cold, oligotrophic to mesotrophic lakes and reservoirs from central and northern parts of temperate zones. $R$. ellipsoidea occurs in methaphyton of warm swamps, in littoral of lakes and in ponds with rich submerse vegetation, mainly in tropical regions. This ecological separation seems to be very delimiting. Morphological differences are really indistinct. The colonies in $R$. ellipsoidea are only more agglomerated, little more compact, and the cells are usually agglomerated. It was the reason why, e.g., Hindák (1984) considers both species as taxonomically identical. Therefore, we consider both species very well recognizable and separable, which should be accepted until molecular studies confirm or reject their identity. Bourrelly (1970) joined to this unified species also $R$. linearis, which differs, however, not only ecologically (cold stenotherm, acidic peat waters in mountains), but also morphologically. In São Paulo State, the studied populations correspond very well to tropical specimens of $R$. ellipsoidea (e.g., in Bourrelly 1961, from Ivory Coast). The population from a small warm pond (temperature $18-26{ }^{\circ} \mathrm{C}$ ) with aquatic plants, has more or less parallely agglomerated cells with pale blue-green content, without granulation.

Based on samples collected from different waterbodies in São Paulo State, 26 species of Chroococcales were identified. They belong to the families Chroococcaceae (02 taxa), Merismopediaceae (12), Microcystaceae (07) and Synechococcaceae (05). Among these 26 species, seven are considered as potentially toxic (Sant'Anna \& Azevedo 2000): Aphanocapsa incerta, Microcystis aeruginosa, M. botrys, M. panniformis, M. viridis, $M$. wesenbergii, and Radiocystis fernandoi. Except for the known 

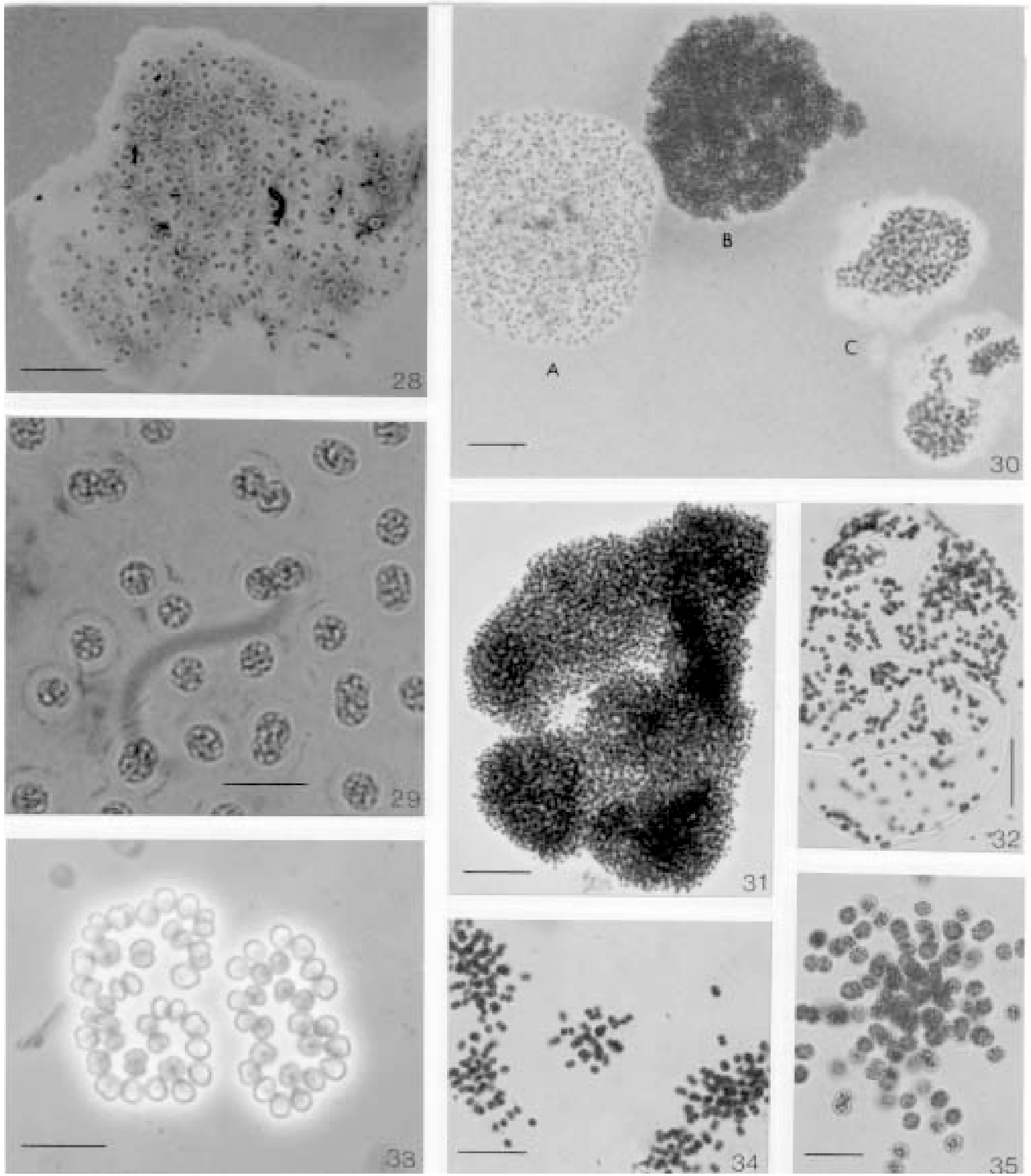

Figures 28-35. Chroococcales species from São Paulo State. 28-29. Microcystis protocystis. 28. General aspect of colony. 29. Detail of cells with individual envelope. 30. Different Microcystis species forming bloom: M. protocystis (A), M. panniformis (B), M. aeruginosa (C). 31. M. panniformis. 32. M. wesenbergii.33. Coelomoron cf. tropicale: atypical colonies showing cells not densely aggregated. 34-35. Radiocystis fernandoi. 34. General aspect of colonies. 35. Colony showing the radial cells organization. Bars $=10 \mu \mathrm{m}(29,33), 50 \mu \mathrm{m}(28,32,34), 20 \mu \mathrm{m}(30,35), 100 \mu \mathrm{m}(31)$. 
potentially toxic species, there is no information about toxicity for the others, mainly those belonging to the picoplankton that are easily neglected in monitoring works. Bacularia and Coelosphaeriopsis are genera recorded for the first time to Brazil.

Acknowledgements - The authors thank Fapesp (Process 97/05488-7) and CNPq (Process 300316/81) for the financial support. They are also indebted to colleagues of Sabesp and Cetesb for the collecting of many samples studied.

\section{References}

AZEVEDO, M.T.P. 1991. Edaphic blue-green algae from the São Paulo Botanical Garden, Brazil. Algological Studies 64:503-526.

AZEVEDO, M.T.P. \& KOVÁCIK, L. 1996. Rhabdogloea brasilica sp. nov. (Chroococcales, Synechococcaceae): morphological and morphometric variability under crossgradient cultures. Algological Studies 83:83-92.

AZEVEDO, M.T.P. \& SANT'ANNA, C.L. 1994a. Cyanostylon gelatinosus, a new species (Chroococcales, Cyanophyceae) from São Paulo State, Brazil. Algological Studies 75:75-78.

AZEVEDO, M.T.P. \& SANT'ANNA, C.L. 1994b. Hormothece geitlerinema: a new edaphic chroococcal Cyanophyceae from São Paulo State, Brazil. Algological Studies 75:78-83.

AZEVEDO, M.T.P. \& SANT'ANNA, C.L. 1999. Coelosphaerium evidenter-marginatum, a new planktic species of Cyanophyceae/Cyanobacteria from São Paulo State, Southeastern Brazil. Algological Studies 94:35-43.

AZEVEDO, M.T.P. \& SANT'ANNA, C.L. 2003. Sphaerocavum brasiliense, a new planktic genus and species of Cyanobacteria from reservoirs of São Paulo State, Brazil. Algological Studies 109:79-92.

AZEVEDO, M.T.P., NOGUEIRA, N.M.C. \& SANT'ANNA, C.L. 1996. Criptógamos do Parque Estadual das Fontes do Ipiranga, São Paulo, SP. Algas, 8: Cyanophyceae. Hoehnea 23:1-38.

AZEVEDO, M.T.P., SOUZA, C.A. \& MENEZES, M. 1999. Synechococcaceae (Cyanophyceae/Cyanobacteria) from tropical brackish water lagoon, Brazil. Algological Studies 94:45-61.

BOURRELLY, P.C. 1961. Cyanophycées de la Cote d'Ivoire. Schweizerische Zeitschrift für Hydrologie 23:209-210.

BOURRELLY, P.C. 1970. Les algues d'eau douce, 3. N. Boubée $\&$ Cie., Paris.

BRANCO, L. H.Z., SANT'ANNA, C.L., AZEVEDO, M.T.P. \& SORMUS, L. 1996. Cyanophyte from Cardoso Island mangroves, São Paulo State, Brazil. 1. Chroococcales. Algological Studies 80:99-111.
CARMICHAEL, W.W. 1996. Toxic Microcystis and the environment. In Toxic Microcystis (M.F. Watanabe, K.I. Harada, W.W. Carmichael \& H. Fujiki, eds.). CRC Press, Boca Raton. p.1-11.

DE-LA-MORA, L.C. 1989. Chroococcales (Cyanophyceae) do Estado de Pernambuco, Brasil, 1: Microcystis. Insula 19:199-212.

FRANCESCHINI, I. 1992. Algues d'eau douce de Porto Alegre, Brésil: taxonomie, composition floristique et peuplements. Bibliotheca Phycologica 92:1-81.

HINDÁK, F. 1984. On the taxonomy of cyanophycean genus Rhabdoderma Schröder = Dactylococcopsis Hansgirg sensu auct. post. Algological Studies 35:121-133.

JOCHIMSEN, E.M., CARMICHAEL,W.W., NA, J., CARDO, D.M., COOKSON, S.T., HOLMES, C.E.M., ANTUNES, B.C., MELOFILHO, D.A.,LYRA, T.M., BARRETO, V.S.T., AZEVEDO, S.M.F.O. \& JARVIS, W.R. 1998. Liver failure and death after exposure to microcystin at a hemodialysis center in Brazil. The New England Journal of Medicine 338:873-878.

KOMÁREK, J. 1989. Studies on the Cyanophytes of Cuba 4-6. Folia Geobotanica \& Phytotaxonomica 24:57-97.

KOMÁREK, J. 1995. Studies on the Cyanophytes (Cyanoprokaryotes) of Cuba, 10: New and little known chroococcalean species. Folia Geobotanica \& Phytotaxonomica 30:81-90.

KOMÁREK， J. \& ANAGNOSTIDIS， K. 1999. Cyanoprokaryota, 1: Chroococcales. In Süsswasserflora von Mitteleurope (H. Ettl, G. Gardner, H. Heynig \& D. Mollenheuer, eds.). Gustav Fischer, Jena, v.19, p.1-548.

KOMÁREK, J. \& CRONBERG, G. 2001. Some chroococalean and oscillatorialean Cyanoprokaryotes from African lakes, ponds and pools. Nova Hedwigia 73:129-160.

KOMÁREK, J. \& KOMÁRKOVÁ-LEGNEROVÁ, J. 1993. Radiocystis fernandoi, a new planktic cyanoprokaryotic species from tropical freshwater reservoirs. Preslia 65:355-357.

KOMÁREK, J., KOMÁRKOVÁ-LEGNEROVÁ, J., SANT'ANNA, C.L., AZEVEDO, M.T.P. \& SENNA, P.A.C. 2002. Two common Microcystis species (Chroococcales, Cyanobacteria) from tropical America, including $M$. panniformis sp. nov. Cryptogamie, Algologie 23:159-177.

KOMÁRKOVÁ-LEGNEROVÁ, J. \& CRONBERG, G. 1994. Planktic blue-green algae from lakes in South Scania, Sweden. Part I. Chroococcales. Algological Studies 72:13-51.

NECCHI JÚNIOR, O. \& SANT'ANNA, C.L. 1986. Taxonomic studies of some Chamaesiphonales (Cyanophyceae) from the State of São Paulo, Southeastern Brazil. Revista Brasileira de Botânica 9:201-206.

SANT'ANNA, C.L. \& AZEVEDO, M.T.P. 2000. Contribution to the knowledge of potentialy toxic cyanobacteria from Brazil. Nova Hedwigia 71:359-385. 
SANT'ANNA, C.L., XAVIER, M.B. \& SORMUS, L. 1988. Estudo qualitativo da Represa de Serraria, SP, Brasil. Revista Brasileira de Biologia 48:83-102.

SANT'ANNA, C.L., BRANCO, L.H.Z. \& SILVA, S.M.F. 1991a. A new species of Gloeothece (Cyanophyceae, Microcystaceae) from São Paulo State, Brazil. Algological Studies 62:1-5.

SANT'ANNA, C.L., SILVA, S.M.F. \& BRANCO, L.H.Z. 1991 b. Cyanophyceae da Gruta que Chora, Ubatuba, SP, Brasil. Hoehnea 18:75-97.

SENNA, P.A.C. 1992. Estudo das Nostocophyceae (Cyanophyceae) do Distrito Federal, 2: Lagoas Joaquim Medeiros e dos Carás. Revista Brasileira de Biologia 52:461-479.

SENNA, P.A.C. 1994. Cyanophyceae de la région est du Distrit Féderal, Brésil, 1. Bulletin du Jardin Botanique National de Belgique 63:81-100.

SENNA, P.A.C. \& FERREIRA, L.V. 1986. Nostocophyceae (Cyanophyceae) da Fazenda Água Limpa, DF, Brasil, 1: Chroococcaceae e Oscillatoriaceae. Revista Brasileira de Botânica 9:91-108.
SENNA, P.A.C., PERES, A.C. \& KOMÁREK, J. 1998. Coelomoron tropicale, a new cyanoprocaryotic species from the tropical zone of São Paulo State, Brazil. Nova Hedwigia 67:93-100.

SENNA, P.A.C., DELAZARI, A. \& SANT'ANNA, C.L. 1999. A new planktic cyanoprokaryotic species, Cyanodityon tropicalis (Cyanophyceae) from Espírito Santo State (Southeastern) Brazil. Algological Studies 94:293-303.

WERNER, V.R. 1988. Cianofíceas planctônicas da lagoa de Tramandaí e da Lagoa do Armazém, Rio Grande do Sul, Brasil. Iheringia 37:33-70.

WERNER, V.R. 2002. Cyanophyceaea/Cyanobacteria no sistema de lagoas e lagunas da Planície Costeira do Estado do Rio Grande do Sul, Brasil. Tese de doutorado, Universidade Estadual Paulista, Rio Claro.

WERNER, V.R. \& ROSA, Z.M. 1992. Cyanophyceae da Estação Ecológica do Taim, Rio Grande do Sul, Brasil. Revista Brasileira de Biologia 52:481-502.

WERNER, V.R. \& SANT'ANNA, C.L. 2000. A new species of Aphanothece (Cyanophyceae, Chroococcales) from shallow coastal lagoon, South Brazil. Nova Hedwigia 70:113-125. 